Pak. j. sci. ind. res. Ser. A: phys. sci. 2018 61A(2) 91-95

\title{
GIS and RS Based Approach for Monitoring the Snow Cover Change in Gilgit Baltistan
}

\author{
Umair Bin Zamir* and Hina Masood \\ Department of Geography, University of Karachi, Karachi-75270, Pakistan
}

(received July 20, 2017; revised March 7, 2018; accepted March 8, 2018)

\begin{abstract}
Snow cover mapping, monitoring, and estimation are a time consuming and complicated process if monitored by traditional means. However, the periodical and precise mapping of snow cover can be done by using optical satellite imagery. Satellite data archive from Landsat (1980-2014) is used with Shuttle Radar Topographic Mission (SRTM) DEM data. The results showed that the total area of snow cover was $27987.21 \mathrm{~km}^{2}$ in 1980 and $26318.05 \mathrm{~km}^{2}$ in 2014 . The variation in snow cover was $1669.16 \mathrm{~km}^{2}$ during 1980 to 2014. The combination of GIS and Remote sensing techniques help in delineating the snow cover pockets that are retreating at the high, moderate and low rate. Furthermore, the district-wise share of snow cover is also calculated.
\end{abstract}

Keywords: remote sensing, snow cover, SRTM, change analysis

\section{Introduction}

Snow cover is considered an important component for understanding the regional climate change. The change in snow cover impacts the socioeconomic and environmental domains like agriculture, water supplies, land management etc. Currently, worldwide climatic change draws growing interest from researchers as well as governments (Man et al., 2014). The use of remote sensing data is useful due to the inaccessibility of high mountainous area. Remote sensing performs the notable as well as continuing part in global climatic change monitoring (Khorram et al., 2012). Considering the actual vastness, distant nature as well as brutal climatic conditions from the snow-covered places, remote sensing is probably the best instrument with regard to extensive as well as repeated research of those places within a relatively inexpensive way (Arora et al., 2011).

Information, which can be found in various scales as well as an improvement within electronic data information, allow common widespread change detection for every environment (Khorram et al., 2012; Kerr and Ostrovsky, 2003). GIS together with remote sensing technologies assists in quick as well as effective methods to evaluate, imagine as well as report the periodic variation in snow-cover (Kaur et al., 2009). Snow cover performs an essential part of the environment programme through altering the power as well as mass transfer between environment and the surface area (Khosla et al., 2011). Snow is the most important land cover in *Author for correspondence: E-mail: binzamir@hotmail.com
Gilgit Baltistan (GB), Pakistan which provides the water for rivers. Snow cover spatial monitoring is a crucial element of investigation since it offers understanding regarding the quantity of water to become anticipated through snowmelt readily available for runoff as well as hydrant (Salomonsona and Appel, 2004). In numerous research and developing actions, up-to-date and reliable information on the dynamic and spatial extent of snow could be useful. Therefore, this information may be used as a better input in climate modeling, hydropower programme, strategic planning, drinking water administration and much more developing actions in the area.

A number of methods have been used for snow cover mapping using multispectral dataset like manual delineation, band ratio, NDSI (Normalize Difference Snow Index) (Salomonsona and Appel, 2006) as well as Visual interpretation, visual and supervised classification (hybrid). Manual delineation techniques such as on-screen digitization has been broadly utilised for mapping and estimation of the snow extent and glacial ice, and specifically, for deglaciation and retreating over different parts of the world (Kulkarni et al., 2007; Khromova et al., 2006; Williams et al.,1997; Hall et al., 1995). Paul (2000) used on screen digitization methods for margins of glaciers through Landsat Images within the Weissmies Area, Switzerland. Shangguan et al. (2006) utilized Landsat data to digitize the outline of a glacier in Muztag Ata and Konggur mountain region. 
The present study attempts to measure the trend of snow cover for the years from 1980 to 2014 in entire Gilgit-Baltistan using multi-temporal satellite data and GIS techniques. The study also calculated the district wise area of snow cover in the study area.

\section{Materials and Methods}

Study area. The northern administrative region, the former Northern area of Pakistan is now known as Gilgit-Baltistan (Hinman, 2012; Weightman, 2005). It lies between $35^{\circ} 21^{\prime} 0^{\prime \prime}$ North to $75^{\circ} 54^{\prime} 0^{\prime \prime}$ East. It borders with Xinjiang of China to the northeast, Jammu, and Kashmir to the southeast, Afghanistan to the north, Khyber Pakhtunkhwa province to the west, and Azad Kashmir to the south (UNPO, 2017). Administratively, it is divided into three divisions (The Express Tribune, 2012), now having ten districts, six in Gilgit division (Gilgit, Ghizer, Diamir, Astore, Hunza and Nagar) and four in Baltistan (Skardu, Shigar, Kharmang and Ghanche) division (The Express Tribune, 2015). It covers approximately $72,971 \mathrm{~km}^{2}$ area. The area is highly mountainous and had 1,800,000 estimated population in 2015 (Burki, 2015). Outside the Polar regions, world's three longest glaciers (Biafo Glacier, the Baltoro Glacier and the Batura Glacier) are found in GB (Gilgit-Baltistan).

For monitoring and mapping purpose of earth surface, one of the most valuable satellite datasets archive above 45 year available from Landsat data (Kennedy et al., 2014; Coppin and Bauer, 1994). Several authors recommended the combination of Landsat bands for snow cover area as red, near infrared and middle infrared (Paul and Hendriks, 2010; Paul et al., 2004). The NDSI is recognized for their own capability to enrich the snow/ice feature (Du et al., 2014; Silverio and Jaquet, 2009). NDSI as following equation (Du et al., 2014):

$$
\mathrm{NDSI}=\frac{\rho \mathrm{B} 2-\mathrm{wB} 5}{\rho \mathrm{B} 2-\mathrm{wB} 5}
$$

where:

$\mathrm{B} 2=$ Band 2; $\mathrm{B} 5=$ Band 5.

The present study utilised Landsat MSS (Multispectral Scanner System) and OLI (Operational Land Imager) datasets of 1980 and 2014 (Table 1). All Landsat scenes were acquired from the Earth Explorer. Four SRTM tiles were obtained from CGIAR (Consultative Group on International Agricultural Research). All processing was done in ArcGIS 10. Snow covered area was manually delineated using on-screen digitization method in a GIS environment. By combining satellite data and SRTM DEM (Digital Elevation Model) with digitized snow cover area was used for accuracy. After digitization, the area of the snow cover was obtained for the year 1980 and 2014.

\section{Results and Discussion}

The present analysis of snow cover for the period of 1980 and 2014 for the entire GB districts is illustrated in Fig. 1. The result demonstrates that the area of snow cover was $27987.21 \mathrm{~km}^{2}$ in 1980 whereas 26318.05 $\mathrm{km}^{2}$ area of snow was found in 2014. Figure 1 also depicts the variation in snow cover between 34 years in the study area calculated as $1669.16 \mathrm{~km}^{2}$. Trend analysis of snow cover pockets that are retreating at very high, high, moderate and low rate are given in Fig. 2 and Table 2. In Fig. 2 where green colour represents the highly decreased area, turquoise represents high, light blue represents moderate and dark blue

Table 1. Satellite image being used in research

\begin{tabular}{cll}
\hline \hline Satellite & Sensor name & Acquisition date \\
\hline Landsat & MSS & 6-Sep-79 \\
& MSS & 14-Sep-79 \\
& MSS & 6 -Sep-80 \\
& MSS & 7-Sep-80 \\
& MSS & $26-$ Sep-80 \\
& MSS & $22-$ Sep-81 \\
& MSS & $14-$ Sep-81 \\
& OLI & $17-S e p-14$ \\
& OLI & $17-S e p-14$ \\
& OLI & $24-S e p-14$ \\
OLI & $28-S e p-14$ \\
\hline \hline
\end{tabular}

Table 2. Districtwise snow cover change

\begin{tabular}{llll}
\hline \hline Name & $\begin{array}{l}\text { Snow cover } \\
1980\left(\mathrm{~km}^{2}\right)\end{array}$ & $\begin{array}{l}\text { Snow cover } \\
2014\left(\mathrm{~km}^{2}\right)\end{array}$ & Status \\
\hline $\begin{array}{l}\text { Ghizer/Yasin, Gupis, } \\
\text { Ishkomen, Punial }\end{array}$ & 6274.93 & 1477.67 & Very high \\
Hunza-Nager & 8640.42 & 8473.59 & High \\
Diamir & 912.49 & 514.82 & High \\
Gilgit & 1341.44 & 623.12 & High \\
Ghanche & 4693.14 & 5153.90 & Moderate \\
Astore & 700.93 & 908.53 & Moderate \\
Skardu/Shigar, Rondu, & 5626.85 & 9391.75 & Low \\
Gultari, Kharmang & & & \\
\hline \hline
\end{tabular}



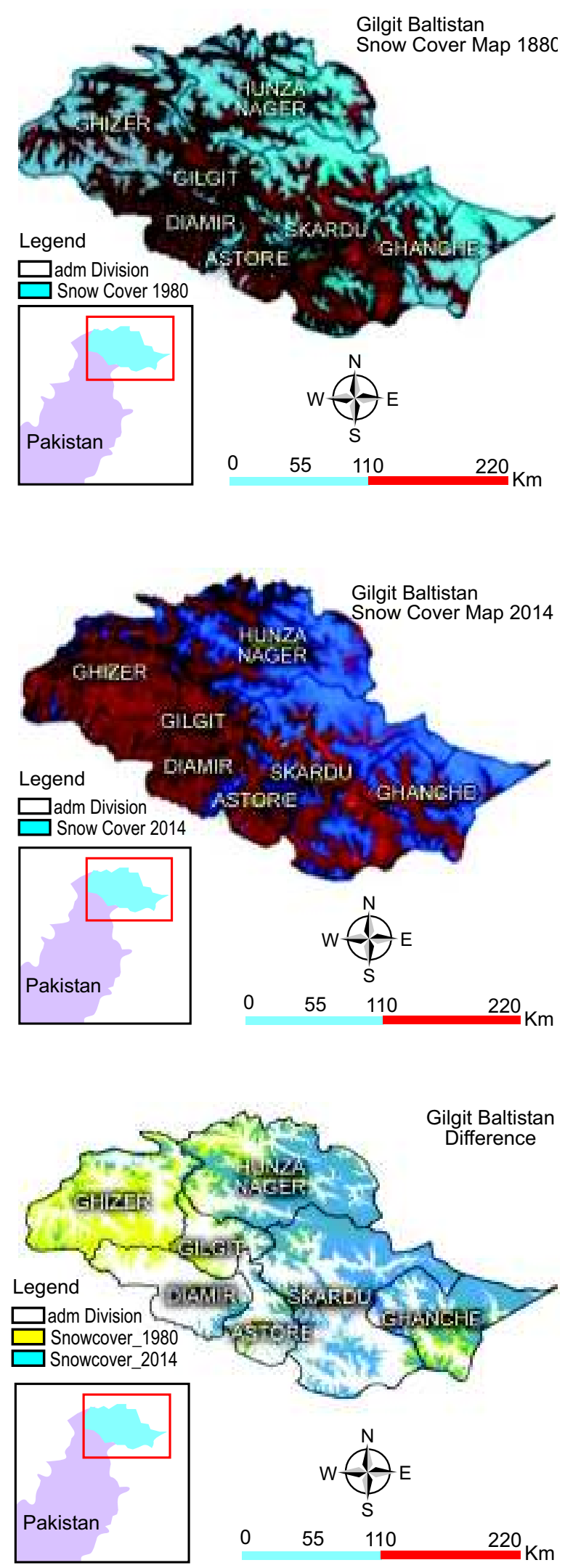

Fig. 1. Snow cover and difference map (1980-2014).
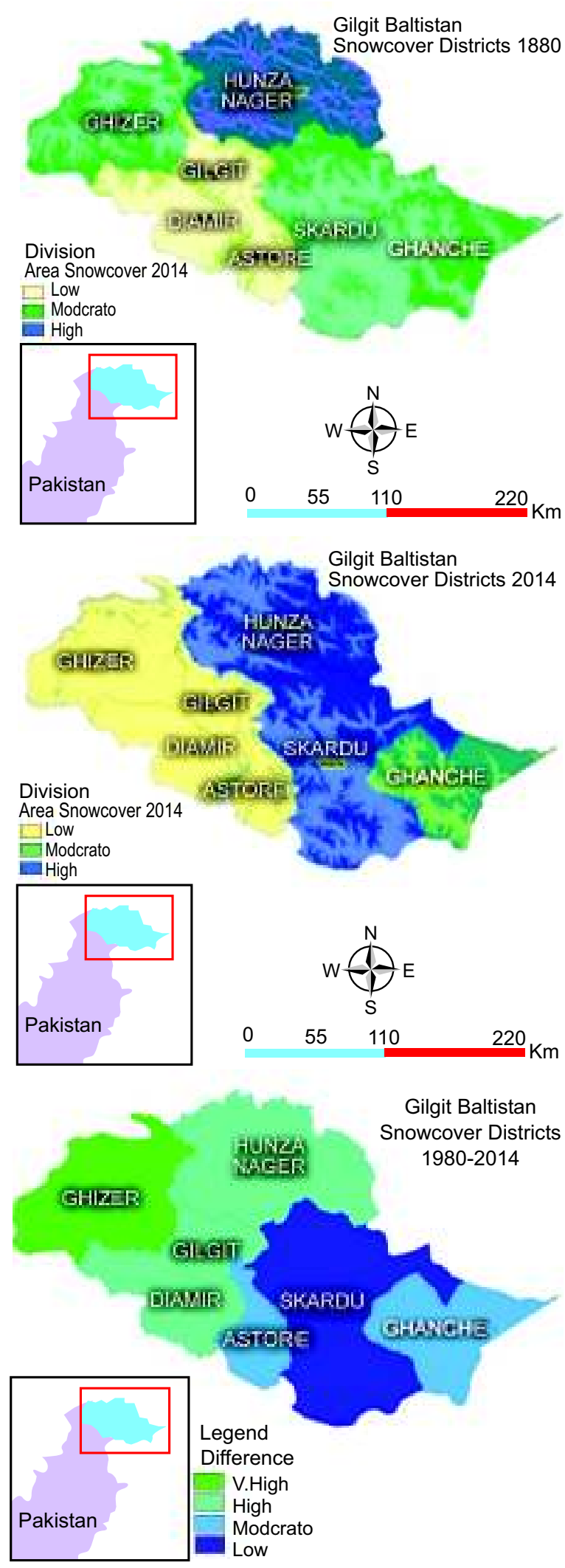

Fig. 2. District wise share and change in snow cover GB. 
represents low changes in the snow cover area. The trends of snow cover pockets retreating are apparent in the past 30 years. Furthermore, the district-wise share of snow cover is also calculated and presented in Table 2. It can be seen that during the past three decades, the snow cover pockets very highly retreated in Ghizer district with $6274.93 \mathrm{~km}^{2}$ to $1477.67 \mathrm{~km}^{2}$, whereas it shrinkage with high rate in Hunza, Gilgit, and Diamir, moderately in Astore and Ghanche districts. The area of snow cover in Hunza-Nager has $8640.42 \mathrm{~km}^{2}$ snow cover in 1980 and decreased in 2014 with $8473.59 \mathrm{~km}^{2}$. The area of snow cover in Diamir district was shrinkage from $912.49 \mathrm{~km}^{2}$ in 1980 to $514.82 \mathrm{~km}^{2}$ in 2014 with $8473.59 \mathrm{~km}^{2}$. In Gilgit, the snow area highly retreated with $1341.44 \mathrm{~km}^{2}$ to $623.12 \mathrm{~km}^{2}$ in 1980 and 2014 . The covered area of snow in Ghanche and Astore districts were $4693.14 \mathrm{~km}^{2}$ to $5153.9 \mathrm{~km}^{2}$ and $700.93 \mathrm{~km}^{2}$ to $908.53 \mathrm{~km}^{2}$ in 1980 and 2014, respectively. The Skardu/ Shigar, Rondu, Gultari and Kharmang show the low retreating trend of snow cover pockets (Table 2).

However, it is evident that the snow-covered area is reducing continuously within the Gilgit-Baltistan and it might be because of climate-related aspects on the regional scale as well as around the world. The regular monitoring associated with snow cover via satellite images of various times might perform an important role within environmental planning as well as hydrological modeling.

\section{Conclusion}

This research offers valuable understanding into the extent as well as nature of snow cover changes, which has happened within the entire Gilgit Baltistan (GB), Pakistan through 1980 to 2014. Satellite data archive from Landsat of 1980-2014 was used and processed in remote sensing and GIS environment to monitor the snow cover of Gilgit-Baltistan area. The present study shows the effectiveness of GIS and remote sensing methods for analysing the extent of snow cover area and their change. The result shows the combination of GIS and remote sensing techniques helps in delineating the snow cover pockets that are retreating at the high, moderate and low rate.

\section{References}

Arora, M.K., Shukla, A., Gupta, R.P. 2011. Digital image information extraction techniques for snow cover mapping from remote sensing data. Encyclopedia of Snow, Ice and Glaciers, pp. 213-232,
Springer, New York, USA.

Burki, S.J. 2015. Historical Dictionary of Pakistan, $4^{\text {th }}$ edition, pp. 228, Rowman \& Littlefield, MD, USA.

Coppin, P.R., Bauer, M.E. 1994. Processing of multitemporal landsat TM imagery to optimize extraction of forest cover change features. IEEE Transactions on Geoscience and Remote Sensing, 32: 918-927.

Du, W., Li, J., Bao, A., Wang, B. 2014. Mapping changes in the glaciers of the eastern Tienshan Mountains during 1977-2013 using multitemporal remote sensing. Journal of Applied Remote Sensing, 8: 084683-084683.

Hall, D.K., Riggs, G.A., Salomonson, V.V. 1995. Development of methods for mapping global snow cover using moderate resolution imaging spectroradiometer data. Remote Sensing of Environment, 54: $127-140$.

Hinman, B. 2012. We Visit Pakistan, 41 pp., Mitchell Lane Publishers, Inc., DE, USA.

Kaur, R., Saikumar, D., Kulkarni, A.V., Chaudhary, B. 2009. Variations in snow cover and snowline altitude in Baspa Basin. Current Science, 96: 1255-1258.

Kennedy, R.E., Andréfouët, S., Cohen, W.B., Gómez, C., Griffiths, P., Hais, M., Healey, S.P., Helmer, E.H., Hostert, P., Lyons, M.B. 2014. Bringing an ecological view of change to Landsat-based remote sensing. Frontiers in Ecology and the Environment, 12: 339-346.

Kerr, J.T., Ostrovsky, M. 2003. From space to species: ecological applications for remote sensing. Trends in Ecology \& Evolution, 18: 299-305.

Khorram, S., Koch, F.H., vanDer Wiele, C.F., Nelson, S.A.C. 2012. Remote Sensing: Springer, New York, USA.

Khosla, D., Sharma, J., Mishra, V. 2011. Snow cover monitoring using different algorithm on AWiFS Sensor data. International Journal of Advanced Engineering Sciences and Technologies, 7: 42-47.

Khromova, T., Osipova, G., Tsvetkov, D., Dyurgerov, M., Barry, R. 2006. Changes in glacier extent in the eastern Pamir, Central Asia, determined from historical data and ASTER imagery. Remote Sensing of Environment, 102: 24-32.

Kulkarni, A.V., Bahuguna, I., Rathore, B., Singh, S., Randhawa, S., Sood, R., Dhar, S. 2007. Glacial retreat in Himalaya using Indian remote sensing satellite data. Current Science, 92: 69-74.

Man, Q., Guo, H., Liu, G., Dong, P. 2014. Comparison of Different Methods for Monitoring Glacier 
Changes Observed by Landsat Images. Paper presented at the IOP Conference Series: Earth and Environmental Science, vol. 17, published online on 18 March, 2014.

Paul, F., Hendriks, J. 2010. Detection and visualization of glacier area changes. In: Remote Sensing of Glaciers: Techniques for Topographic, Spatial and Thematic Mapping of Glaciers, Pellikka, P. K. E. and Rees, G. (eds.) s. xxv, 330 pp., CRC Press, Boco Raton FL, USA.

Paul, F., Huggel, C., Kääb, A. 2004. Combining satellite multispectral image data and a digital elevation model for mapping debris-covered glaciers. Remote Sensing of Environment, 89: 510-518.

Paul, F. 2000. Evaluation of Different Methods for Glacier Mapping using Landsat TM. Paper presented at the Workshop on Land Ice and Snow, Dresden, Germany.

Salomonson, V.V., Appel, I. 2006. Development of the Aqua MODIS NDSI fractional snow cover algorithm and validation results. IEEE Transactions on Geoscience and Remote Sensing, 44: 1747-1756.

Salomonson, V., Appel, I. 2004. Estimating fractional snow cover from MODIS using the normalized difference snow index. Remote Sensing of Environment, 89: 351-360.

Shangguan, D., Liu, S., Ding, Y., Ding, L., Xiong, L.,
Cai, D., Li, G., Lu, A., Zhang, S., Zhang, Y. 2006. Monitoring the glacier changes in the Muztag Ata and Konggur Mountains, East Pamirs, based on Chinese Glacier Inventory and recent satellite imagery. Annals of Glaciology, 43: 79-85.

Silverio, W., Jaquet, J.M. 2009. Prototype land-cover mapping of the Huascara'n Biosphere Reserve (Peru) using a digital elevation model, and the NDSI and NDVI indices. Journal of Applied Remote Sensing, 3: 033516-033519.

The Express Tribune, 2015. Dividing governance: Three new districts notified in G-B. Website URL: https:// tribune.compk/epaper/. Retrieved 7 June 2017.

The Express Tribune, 2012. Gilgit-Baltistan divided into three divisions. Website URL: https://tribune. com.pk/epaper/. Retrieved 7 June 2017.

UNPO, 2017. Gilgit Baltistan: Impact of Climate Change on Biodiversity. www.unpo.org. Retrieved 5 April 2017.

Weightman, B.A. 2005. Dragons and Tigers: A Geography of South, East, and Southeast Asia, $3^{\text {rd }}$ edition, John Wiley and Sons, USA.

Williams, R.S., Hall, D.K., Sigurðsson, O., Chien, J.Y. 1997. Comparison of satellite-derived with groundbased measurements of the fluctuations of the margins of Vatnajökull, Iceland, 1973-1992. Annals of Glaciology, 24: 72-80. 